ordinary nervous concentration of attention common to the Felidx before " pouncing." He speaks of larks being attracted in the South of France by means of an octagonal box holding a mirror mounted on a pivot which is turned by the wind. The reflected rays of sunlight dazzle and delight the birds, and they approach near enough to be caught by a spring net. The preliminary phase, that of attention, wherein curiosity perhaps predominates, is illustrated in the known trick of a fox anusing ducks by rolling itself down a bank, as also in the perilous interest excited in a loon by a handkerchief waved by an unseen hand. Many must have experienced, on looking over very bigh galleries upon floors beneath, or over sheer precipices, an almost uncontrollable impulse to throw themselves headlong down. Can this feeling be described as akin to "fascination"?

Amer. Mus. Nat. Hist., N. Y., October 28 L. P. Gratacap

A. Percy Smith.-The little centipede is Geophilus electricus, well known to be occasionally luminous.

\section{HOMAGE TO MR. DARWIN}

$\mathrm{O}^{\mathrm{s}}$ Wednesday, November 3, a deputation from the Yorkshire Naturalists' Union waited upon Mr. Darwin at his residence, Down, Beckenham, Kent, for the purpose of presenting him with an address expressive of admiration for his long devotion to scientific research, and appreciation of the great and important results to which his investigations have led. Prof. Williamson, F.R.S., of the Owens College, Manchester, who is the president of the Union for the current year, was prevented from accompanying the deputation by the pressure of his professorial duties. The deputation arrived at Mr. Darwin's residence about I p.m., and was received in a most hearty manner by the great naturalist himself, Mrs. Darwin, and other members of the family. The members of the deputation were introduced individually to $\mathrm{Mr}$. Darwin by Dr. Sorby, vice-president of the Union, and then the interesting ceremony of the presentation of the address was at once proceeded with. After a few words on the work of the Union by Dr. Sorby, the address was read by $\mathrm{Mr}$. Thomas Hick, B.A., B.Sc., and formally presented to Mr. Darwin by Ur. Sorby. Replying to the address, Mr. Darwin assured the deputation of his decp sense of the honour the Yorkshire Naturalists' Union had conferred upon him on that occasion, and only regretted that he had not done something more deserving of such an honour. He had no idea previously that there was so strong a body of working naturalists in Yorkshire, but was pleased to learn that such was the fact, and to find from the Transsactions that had been forwarded to him that they were doing useful work. Coming from such a body, the address was all the more gratifying to him, though he still feared he hardly merited the good things that hac been said of him. The address which had been presented to him he and his family would for ever treasure and preserve, and he desired to express his warmest thanks, both to the deputation and those whom they represented, for it, and for the kind and considerate manner in which everything connected with it had been arranged. Subsequently the deputation were entertained at luncheon, and having spent a short time in familiar conversation with their hospitable host and his family, took their departure amid mutual expressions of kindness and regard.

The following is the text of the Address, which is dated August last :-

To Charles Darwin, LL.D., M.A., F.R.S. \&̈., \&.c.

SIR, - The Council and Members of the Yorkshire Naturalists' Union, all of whom, with scarcely an ex:eption, are working students of one or more of the various branches of natural bistory, desire to express to you in a most respectful manner, and yet with the greatest cordiality, their admiration of your life-long devotion lo original scientific research and their high appreciation of the almost unraralleled success of the investiga!ions by which you have contributed so largely to the modern development and progress of biological science.

More especially do they desire to congratulate you on the fact that your great work on the Origin of Species will come of age at an early date, and that your life ha; been spared long enough to enable you to see the leading principles therein enunciated accepted by most of the eminent naturalists of the day. On the conspicuous merits of that and of your other pub. lished works they need not dwell, as those merits have been recognised and admitted even by those who have dissented most strongly from the conclusions at which you have arrived. They may nevertheless be permitted to remind you that your writings have been instrumental in giving an impetus to biological and palæontological inquiries which has no precedent in the history of science, except perhaps in that which followed the promulgation of the gravitation theory of Newton, and that which was due to the discovery of the circulation of the blood by Harvey.

One of the most important results of your long-continued labours, and one for which you will be remembered with honour and reverence as long as the human intellect exerts itself in the pursuit of natural knowledge, is the scientific basis you have given to the grand Doctrine of Evolution. Other naturalists, as you yourself have shown, had endeavoured to unravel the questions that had arisen respecting the origin, classification, and distribution of organic beings, and had even obtained faint glimpses of the transformation of specific forms. But it was left to you to show, almost to demonstration, that the variations which species of plants and animals exhibit, and in natural selection through the struggle for existence, we have causes at once natural, universal, and effective which of themselves are competent not only to explain the existence of the present races of living beings, but also to connect with them, and with one another, the long array of extinct forms with which the palre ontologist has made us familiar.

Farther, the Yorkshire Naturalists are anxious to place on record their firm conviction that in the care, the patience, and the scrupulous conscientiousness with which all your researches have been conducted; in the ingenuity of the experiments you have devised; and in the repeated verifications to which your results have been submitted by your own hands, you have furnished an example of the true method of biological inquiry that succeeding generations will deem it an honour to follow, and that cannot but lead to still further conquests in the domain of organic nature.

In presenting this small tribute of their high regard and estecm, the members of the Yorlishire Naturalists' Union cannot but hope and pray that many years of happiness and usefulness may yet remain to you, and that our Science and Literature may be still further enriched with the results of your researches.

(Signed) William C. Williamson, F.R.S., President, H. C. SORBY, LL.D., F.R.S., Vice-President, George Brook, ter. F.L.S., Secretary,

WM. Denison RoebuCK, Secretary,

and Eleven other representative Officials.

\section{THE ATOMIC WEIGHT OF BERYLLIUM}

FOR some time chemists bave been doubtful what value to assign to the atomic weight of beryllium. Some years ago Prof. Emmerson Reynolds determined the specific heat of this metal to be $0^{\circ} 642$; this number muitiplied into $9^{\circ} \mathrm{I}$ gave $5^{\circ} .8$ as the atomic heat of beryllium; in other words it confirmed the generally accepted atomic weight. In 1878 Nilson and Pettersson re-determined the specific heat of beryllium, and found the number 0.408 for the temperature interval $0^{\circ}-100^{\circ}$; hence these chemists concluded that the atomic weight of the metal must be increased by one-half $\left(13^{.6} \times 0^{\circ} 408=5^{\circ} 6\right)$. If $\mathrm{Be}=9^{\circ} \mathrm{I}$ the oxide of beryllium is $\mathrm{BeO}$, and the metal is placed in the magnesium group; but if $\mathrm{Be}=13.6$ the oxide is $\mathrm{Be}_{2} \mathrm{O}_{3}$, and the metal is placed in the aluminium group. But there is no place in Mendelejeff's classification of the elements according to the magnitude of their atomic weights for a metal with the atomic weight $13 \cdot 6$, forming an oxide $\mathrm{M}_{2} \mathrm{O}_{3}$, and exhibiting the properties of beryllium. The value of Mendelejeff's classification is however so great that chemists were not inclined to alter the atomic weight of beryllium except upon most cogent evidence. 